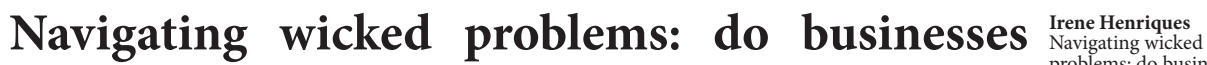 have a role?

\section{Irene Henriques}

It is a pleasure and honor to be invited to speak at the 2019 SinergieSIMA Management Conference here in Rome. As a professor of Sustainability \& Economics who has been studying sustainability and business for over 25 years, the question I am often asked is: Have things improved across time? My response is "it depends...".

Environmental and social issues are not alike. Some are tame in that the issue originates from a specific source and can be reduced by the source by choosing to reduce or eliminate certain activities that cause the problem, but others are wicked (e.g., income inequality, climate change, information overload, achieving zero waste) because they originate from multiple sources and cannot be reduced unless all sources agree to change their behavior. The wickedness does not only stem from their biophysical complexity but also from multiple stakeholders' perceptions of them and of potential trade-offs associated with problem solving. In my research with Michael Barnett and Bryan Husted (Barnett et al., 2018, p. 128), we summarize the differences in Table 1.

Tab. 1: Tame versus Wicked Environmental Problems

\begin{tabular}{|c|c|c|}
\hline Characteristics & Tame Environmental Problem & Wicked Environmental Problem \\
\hline $\begin{array}{l}\text { Definition and } \\
\text { nature of the } \\
\text { problem }\end{array}$ & $\begin{array}{l}\text { Clear definition of the problem elicits the } \\
\text { solution } \\
\text { Outcome determined by whether } \\
\text { solution is successful or not } \\
\text { - Scientific-based protocols guide } \\
\text { solutions } \\
\text { - Problem associated with low } \\
\text { uncertainty as to system components } \\
\text { and outcomes } \\
\text { - Shared values as to desirability of } \\
\text { outcomes } \\
\text { - Problem largely unchanging across } \\
\text { time } \\
\text { - Problem usually confined to a specific } \\
\text { area }\end{array}$ & $\begin{array}{l}\text { Disagreement as to definition of the } \\
\text { problem as each possible solution } \\
\text { changes the problem } \\
\text { No single outcome - assessment whether } \\
\text { things are better or worse } \\
\text { - Solution(s) based on judgement of } \\
\text { multiple stakeholders } \\
\text { - Problem is associated with high } \\
\text { uncertainty as to system components } \\
\text { and outcomes } \\
\text { - No shared values with respect to } \\
\text { societal goals } \\
\text { - Problem changes over time } \\
\text { - Problem not confined to specific area } \\
\text { or region }\end{array}$ \\
\hline $\begin{array}{l}\text { Social context } \\
\text { and type of } \\
\text { knowledge }\end{array}$ & \begin{tabular}{|l} 
Handled by limited number of \\
stakeholders including those who \\
created the problem - a mostly private \\
problem \\
- Solution dictates the knowledge \\
necessary to proceed
\end{tabular} & $\begin{array}{l}\text { Public problem dispersed amongst a } \\
\text { host of actors that cannot be resolved by } \\
\text { a single actor alone } \\
\text { - Requires co-creation of knowledge } \\
\text { to bridge social, environmental \& } \\
\text { economic tensions }\end{array}$ \\
\hline $\begin{array}{l}\text { Problem } \\
\text { resolution }\end{array}$ & $\begin{array}{l}\text { Few stakeholders, so easier to bargain for } \\
\text { solution }\end{array}$ & $\begin{array}{l}\text { No definitive solution; depends on } \\
\text { judgements of many key stakeholders }\end{array}$ \\
\hline $\begin{array}{l}\text { Examples of } \\
\text { problems }\end{array}$ & $\begin{array}{l}\text { Point pollution (single source of } \\
\text { pollution is known), food contamination, } \\
\text { soil erosion, energy efficiency }\end{array}$ & $\begin{array}{l}\text { Climate change, income inequality, } \\
\text { biodiversity, deforestation, water, } \\
\text { poverty }\end{array}$ \\
\hline
\end{tabular}


Sinergie

Vol. 38, Issue 1, 2020

Across time I have seen businesses improve their ability in dealing with tame problems such as end-of-pipe pollution, energy conservation, gender equality and diversity within their own organizations. On the wicked problem side, however, the jury is still out. The main question my research seeks to address is: How can businesses successfully navigate wicked problems and with whom should they partner when seeking to do so?

Wicked problems occur within what Rittel and Webber (1973, p. 160) call an open societal system where problems are ill-defined, dynamically complex, and "rely on elusive political judgment for resolution". Wicked problems require a system thinking approach. Wicked problems are public problems that are dispersed amongst a host of actors that cannot be resolved by a single actor alone. Let's play a thought experiment. Consider climate change. Defining the problem requires knowledge of the existing condition, the desired condition and the complex causal networks within which the problem really lies. These networks include both the physical and societal systems. A problem definition that states that burning fossil fuels causes climate change would inevitably result in a solution that stipulates we stop burning fossil fuels. Negotiating such a solution, however, would be extremely difficult as energy is a critical human need affecting a host of stakeholders and self-interested parties worldwide. A different solution would entail investment in clean technologies, but such a solution begs the question of who will undertake such an investment if fossil fuels continue to dominate. Another solution would suggest that countries with the greatest emissions should be obliged to reduce their emissions accordingly. The social context and the type of knowledge needed to address the problem make the decision process messy despite scientific evidence that climate change has moved firmly into the present and is affecting health, water, energy, and agriculture, thereby generating other wicked problems such as increased food insecurity and threats to national security.

Sustainability issues tend to be wicked problems that require cooperation across parties and over time to define and resolve. Barnett, Henriques and Husted (2018) explain why firms selectively responding to the most powerful, legitimate, and urgent demands of their stakeholders will not bring about sustainability and offer suggestions on what we should do considering this shortcoming. We argue that without government intervention, self-interested stakeholders will tend to pressure firms to move away from the complex, long-term challenges of wicked problems. Yet, stakeholder pressure is also necessary, as without it, industries may selfregulate in self-serving ways. Our analysis thus suggests that collaboration between business, government, and stakeholders is necessary to resolve the wicked problems of sustainability.

More specifically, wicked problems require co-creation of knowledge to bridge social, environmental and economic tensions (Barnett et al., 2018). So, what is co-creation? A co-creation process, by allowing participants to critically reflect on each other's views, enables participants to reflect not only on their own preferences and viewpoints but also on how they might be changed (Batie, 2008). Such co-creation is emerging in the automobile sector where entrepreneurial firms have found creative ways to circumvent the drawbacks of electric vehicles (e.g., cost, range, charging time), forcing 
the incumbents to critically reflect on the future of the motor engine and invest in electric vehicles as a possible alternative to the motor vehicle given a carbon-constrained future (Bohnsack et al., 2014) despite the "oil industry-backed attempt to discredit electric vehicles (EVs) and dismantle progress on transportation electrification by peddling misinformation through industry funded studies" (Todd Whitman, 2018).

My research also suggests that greater leadership and cooperation is needed. Wicked problems involve uncertainty and disagreement over scale, scope and timeframe to resolve. Sustainability, for example, is an intergenerational dilemma where decisions made today will affect future generations. Unfortunately, self-interested and myopic firms and stakeholders can hinder the co-creation process. A 16-year-old climate activist, Greta Thunberg, is emphasizing this intergenerational aspect by stating "We deserve a safe future. And we demand a safe future".

Government has the power and ability to bring actors to the table and to set the collaborative agenda on wicked problems. Nobel laureate Elinor Ostrom argued that a "polycentric approach" with experimental efforts at multiple levels (governments, business, and community) is needed to assess and compare the veracity and efficiency of solution strategies to wicked problems across ecosystems and avoid free riding (Ostrom, 2014). Companies are leaders in piloting/designing products, can we not work together to pilot/design solutions to problems that will affect us all?

There is an urgent need to design sustainable business models. A business model describes the "design or architecture of the value creation, delivery and capture mechanisms employed" (Teece, 2010, p. 179). A sustainable business model seeks to address environmental/sustainability issues. It requires introducing sustainable thinking into the four elements of a business model, namely, the value proposition, the supply chain, the customer interface and the financial model (Boons \& Lüdeke-Freund, 2013).

I also believe that sustainable thinking needs to be introduced at the regional level. Examples of a circular economy involving a whole city exist in China where the eco-industrial initiatives are mainly designed, supported and managed by central governments (Hu et al., 2011). In Germany and Japan, governments and industry provide large incentives to support clean production initiatives or eco-industrial parks (Mathews and Tan, 2011; Triebswetter and Hitchens, 2005). But what happens in regions where governments are unable or unwilling to undertake or support such initiatives via changes in regulations, institutions or incentives? Working with colleagues at the EGADE Business School in Monterrey, Mexico, we set out to pilot a bottom-up circular value ecosystem governance framework in which government is not the main driver of the eco-initiatives in a village outside of Monterrey (Aguiñaga et al., 2018). Figure 1 depicts the existing extended value chain that maps out the flow of materials from each process and identifies all the residuals generated in order to further analyze the best options available for its transformation to valuable products. We then measured, communicated and engaged community stakeholders in the circular potential of the region's sustainable readiness under different scenarios. 


\section{sinergie}

Vol. 38, Issue 1, 2020

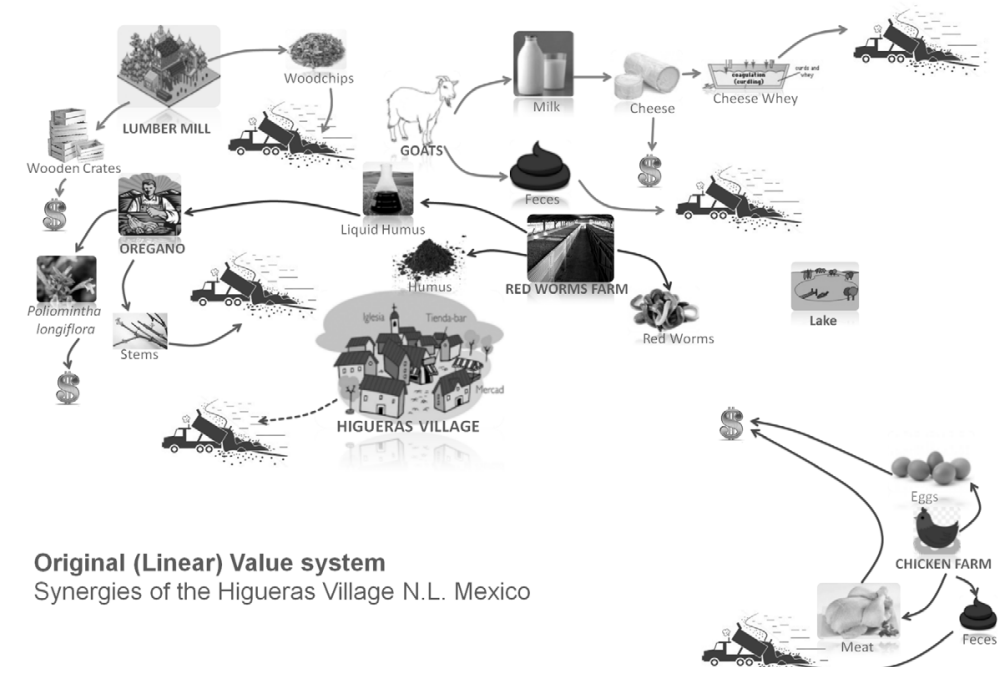

Source: Aguiñaga et al., 2018, p. 191

Figure 2 sets out the synergy map of the village's main stakeholders and the circular economic value flows - our aspirational model. Aguiñaga, Henriques, Scheel and Scheel (2018, p. 195) suggest that for a communitylevel circular value ecosystem governance approach to succeed you require "1) the building of stronger community trust by seeking the participation of stakeholders, especially those that are trust-laden, so as to establish a shared vision of what a resilient, equitable and sustainable community would look like; 2) the encouragement of greater collective action through partnerships with civil society and business to compensate for the lack of environmental leadership from government; 3) the placement of greater efforts in providing information and support in the development of technologies or services that sustainable entrepreneurs can use to transform residues into valuable economic increasing returns; 4) the seeking of support from government and religious officials so as to increase the framework's political (access to public resources, for example) and social legitimacy; and 5) the seeking of seed funding opportunities to support and encourage community and entrepreneurial involvement especially if the region is impoverished". Experimentation is key and the pilot provided valuable information on the process that involved an entire community. 


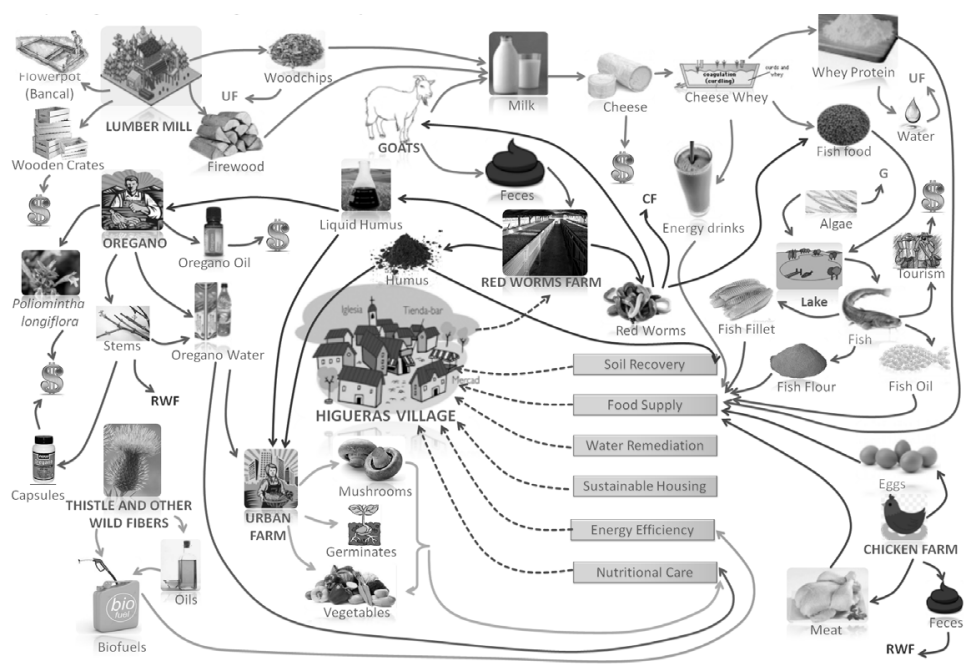

Wicks and Freeman (1998) argued a few decades ago that the purpose of organization studies should be to enable people to live better lives; a clearly normative intent. Research should be focused on discovering or creating innovative ways to achieve this goal. Here again, experimentation is critical. As researchers, we need to move beyond impacts on specific stakeholders by linking firm-level outcomes to impacts at the societal level. The key is to understand the relationship between changes at the firm level and changes at a population or ecosystem level. The development of conceptual models and the use of spatial methods are essential to linking these levels (Doh and Hahn, 2008).

Let me conclude with

It is among those nations that claim to be the most civilized, those that profess to be guided by a knowledge of laws of nature, those that most glory in the advance of science, that we find the greatest apathy, the greatest recklessness, in continually rendering impure this all-important necessity of life...

Alfred Russel Wallace (Naturalist and Explorer) in Man's Place in the Universe, 1903.

Although this was written in 1903, it is even more relevant today. Designing and producing impactful research is more important than ever and I call on my management colleagues to join me in this effort.

\section{References}

AGUINAGA E., HENRIQUES I., SCHEEL C., SCHEEL A. (2018), "Building resilience: A self-sustainable community approach to the triple bottom line", Journal of Cleaner Production, vol. 173, pp. 186-196. 


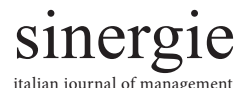

Vol. 38, Issue 1, 2020

BARNETT M., HENRIQUES I., HUSTED B.W. (2018), "Governing the void between stakeholder management and sustainability", Advances in Strategic Management, vol. 38, pp. 121-143.

BATIE S.S. (2008), "Wicked problems and applied economics", American Journal of Agricultural Economics, vol. 90, n. 5, pp. 1176-1191.

BOONS F., LUDEKE-FREUND F. (2013), "Business models for sustainable innovation: State-of-the-art and steps towards a research agenda", Journal of Cleaner Production, vol. 45, pp. 9-19.

BOHNSACK R., PINSKE J., KOLK A. (2014), "Business models for sustainable technologies: Exploring business model evolution in the case of electric vehicles", Research Policy, vol. 43, n. 2, pp. 284-300.

DOH J.P., HAHN E.D. (2008), "Using Spatial Methods in Strategy Research", Organizational Research Methods, vol. 11, n. 4, pp. 659-681.

HU J., XIAO Z., ZHOU R., DENG W., WANG M., MA S. (2011), “Ecological utilization of leather tannery waste with circular economy model", Journal of Cleaner Production, vol. 19, n. 2-3, 221-228.

MATHEWS J.A., TAN H. (2011), "Progress toward a circular economy in China: The drivers (and inhibitors) of eco-industrial initiative", Journal of Industrial Ecology, vol. 15, n. 3, 435-457.

NEUGEBAUER F., FIGGE F., HAHN T. (2016), "Planned or emergent strategy making? Exploring the formation of corporate sustainability strategies", Business Strategy and the Environment, vol. 25, n. 5, pp. 323-336.

OSTROM E. (2014), "A polycentric approach for coping with climate change", Annals of Economics and Finance, vol. 15, n. 1, pp. 97-134.

RITTEL H.W.J., WEBBER M.M. (1973), "Dilemmas in a general theory of planning”, Policy Sciences, vol. 4, n. 2, pp. 155-169.

TODD WHITMAN C. (2018, June 29) Oil industry is 'peddling misinformation' about electric vehicles. CNBC News. Retrieved from https://www.cnbc. com/2018/06/26/electric-vehicles-will-prevail-despite-oil-industrymisinformation.html

TRIEBSWETTER U., HITCHENS D. (2005), “The impact of environmental regulation on competitiveness in the German manufacturing industry - A comparison with other countries of the European Union", Journal of Cleaner Production, vol. 13, n. 7, pp. 733-745.

WALLACE A.R. (1903), Man's Place in the Universe, McClure, Phillips, New York.

WICKS A.C., FREEMAN R.E. (1998), "Organization studies and the new pragmatism: Positivism, anti-positivism, and the search for ethics", Organization Science, vol. 9, n. 2, pp. 123-140.

sinergie

ISSN 0393-5108

Academic or professional position and contacts DOI $10.7433 / \mathrm{s} 111.2020 .02$
pp. $15-20$

pp. $15-20$

Irene Henriques

Professor of Sustainability and Economics

Schulich School of Business, York University - Canada

e-mail: ihenriques@schulich.yorku.ca

\section{S I

